\title{
AGROEXTRACTIVISM IN THE AMAZON: THE SPECIFICITIES OF RELATIONS WITH THE GLOBAL MARKET
}

\section{${ }^{1}$ Rute Holanda Lopes, ${ }^{2}$ Suelânia Cristina Gonzaga de Figueiredo, ${ }^{3}$ Kátia Viana Cavalcante, ${ }^{4}$ Elizangêla de Jesus Oliveira, ${ }^{5}$ Maria Francisca Silva Bastos, 6 Jéssica Lahís Silva Bastos de Menezes and ${ }^{*, 7}$ David Barbosa de Alencar}

\author{
${ }^{1}$ Institute of Exact Sciences and Technology (ICET) - Federal University of Amazonas (UFAM) - Brazil \\ ${ }^{2}$ Academic Department, University Center FAMETRO, Amazon-Brazil \\ ${ }^{3}$ Faculty of Information and Communication - Federal University of Amazonas (UFAM) - Brazil \\ ${ }^{4}$ Institute of Exact Sciences and Technology (ICET) - Federal University of Amazonas (UFAM) - Brazil \\ 5Teacher of Postgraduate Courses at Ser Educacional - UNINORTE, Amazonas - Brazil \\ ${ }^{6}$ Member of the OAB / AM Legal Improvement Commission (2016/2021), Amazonas - Brazil \\ 7Institute of Technology and Education Galileo of Amazon - ITEGAM, Brazil
}

\section{ARTICLE INFO}

Article History:

Received $03^{\text {rd }}$ March, 2020

Received in revised form

$07^{\text {th }}$ April, 2020

Accepted $16^{\text {th }}$ May, 2020

Published online $29^{\text {th }}$ June, 2020

\section{Key Words:}

Agroextractivism;

Productive chain;

Social responsability.

\begin{abstract}
The inclusion of Amazonian communities in the productive chain of industrialized products is usually defended as an option for sustainable development for these communities and for improving the production process as a whole by reducing chemical bases and the use of sources of ecological raw materials. However, experience shows that, in many cases, the activity is started and later abandoned by the prospecting companies. A case study was carried out in the Santo Antônio do Abonari Community in the municipality of Presidente Figueiredo - AM, which aimed to analyze its insertion in the cosmetics production chain as a supplier of buriti oil to industries that produce or benefit this product for companies in this sector. It was found that the insertion of a community of family farmers in the global economy, needs to be planned through an in-depth study that involves a multidisciplinary team for the initial assessment and monitoring during the first productive cycles so that local populations can assimilate the knowledge and management, production and storage practices to guarantee quality within the technical specifications of each product and conditions for maintaining the activity through good management and financial control practices. This monitoring must also be done by the public sector, mainly with the provision of technical assistance and with the supervision and search for commercial agreements to guarantee the remuneration of those involved in the production and in compliance with the current legislation.

Copyright (C) 2020, Rute Holanda Lopes et al. This is an open access article distributed under the Creative Commons Attribution License, which permits unrestricted use, distribution, and reproduction in any medium, provided the original work is properly cited.

Citation: Rute Holanda Lopes, Suelânia Cristina Gonzaga de Figueiredo, Kátia Viana Cavalcante et al., 2020. “Agroextractivism In The Amazon: The Specificities Of Relations With The Global Market”, International Journal of Development Research, 10, (06), 37005-37012.

\section{INTRODUCTION}

The exploitation of natural resources and environmental pollution took on proportions that led to the review of the production process, the creation of national and international regulations and the scientific debate on the subject. Drucker (1989) states that the 20th century witnessed the emergence of a new and important task: to protect the nature of human beings. A process of seeking improvements in procedures and products is initiated that woulSd make it possible to make better use of natural resources and reduce industrial and domestic waste. The concern of environmentalists wins public opinion by forcing companies to adhere to the process of environmental protection. The concern regarding the use of raw materials, energy and the release of solid, liquid and gaseous effluents is relatively recent and has important implications for various sectors of human activity, highlighting the reorientation of scientific research for the rational use of resources and priority guarantee conservation (Clemente and Higashi, 2000). This concern leads to a process of consumer behavioral change, with a direct influence on extractive issues. 
First, consumers began to desire products that respect the environment, minimizing aggressions during extractive processes. And in a second moment, they realized that the use of natural and / or organic products are better for their health and quality of life, as well as for the planet. With the increase in this audience, new industries and companies emerged in order to offer natural or organic products. With the success of these companies, many industries started to change their mode of production creating specific lines for this type of product or acquiring successful companies already existing. Among these, organic, natural cosmetics and biocosmetics stand out, followed by the pharmaceutical and nutraceutical food industries. However, cosmetic companies have gained prominence for their consumer public who have quickly joined the use of ecological products, more aware that they stand out from other consumers for their preference for this type of products, offering to pay a higher price for a product that meets these criteria. APEX-Brasil (2008) considers that the ecological consumer is willing to pay up to $15 \%$ more for a natural cosmetic.

This widespread growth puts the theme in evidence and shows advantages and disadvantages, opportunities and threats. On the one hand, there are the countries that produce and hold technology and on the other, the countries that supply organic material, which in most cases do not have the capacity to offer the final product and therefore have an unfavorable position. This scenario is confirmed by Genamaz (2012) when reporting that the expansion of the natural cosmetics industry has resulted in strong questions in countries with biodiversity under two distinct aspects: 1st) impacts of extractivism and 2nd) collection of raw material. Regulating the access of cosmetic companies to natural resources is essential. In this case, it is necessary to institutionalize the collection of materials, in particular flora, in order to avoid biopiracy and / or the extinction of the species incorporated in the production process. In Amazonas, this reality aggregates the discourse of sustainable development, since the extractive activity, when integrated with productive chains of large industries, could bring financial benefits to extractivists and the communities in which they live. However, this reality is still little studied and is based on political, industrialist and marketing discourse used by these companies. Miguel (2007) highlights that with regard to the Amazon, it is necessary to analyze how this activity contributes to development on a sustainable basis. It is necessary to assess whether these models are capable of adding value to the regional product, incorporating new technologies, taking advantage of biodiversity on a sustainable basis and sharing the benefits with the local communities included in this process.

According to Suframa (2012) in Amazonas, within the production chain of herbal medicines and cosmetics, there are four segments: 1) Supplier of raw materials; 2) Crude oil extraction plants; 3) Vegetable oil refining industry and 4) Phytotherapy and cosmetics industry. In this way, the local production chain is integrated with global chains, suppliers from Amazonian communities such as Santo Antonio do Abonari, sell their products to local or national vegetable oil refinement industries and these benefit the crude oil and sell the product with a quality superior to medium and large size industries inside and outside the country and they produce organic or biocosmetics cosmetics and sell to consumers spread across several countries worldwide. One of the recurring problems in extractive products is that the supply is generally unable to meet the growing market demand as happened with rosewood, rubber, wood, among others. According to Homma, Matos and Menezes (2005) domestication becomes inevitable when the extractive sector is unable to meet the demand of a growing market, extraction will only be able to survive as long as the market is small or the natural stock is sufficient. However, this scenario does not apply to the market for ecological products, since its consumers belong to a peculiar market niche, they are demanding as to the origin of the raw material and how to remove it from nature, prefer the management of natural resources with environmental certifications to monoculture that would de-characterize extraction and sustainability of the process as a whole.

Thus, through agroextractivism, the Amazonian man inserts himself in the global economy as a supplier of raw material for a production chain that meets a demanding demand in different parts of the planet. With this, he starts to suffer pressures that alter his perception placing him within a new reality that makes him more and more specialized and dependent on the capitalist system, modifying his worldview, his customs, his culture and their way of living and relating in society. Kageyama (2004) states that the defining elements of the rural have been modified throughout history, gaining new contours: the large property no longer reigns absolute, agriculture has modernized, the rural population has started to obtain income in the vicinity of the cities, the very industry has penetrated rural areas and cultural differences between the countryside and the city have been reduced. Thus, it is observed, as in the case studied, an approach that brings change to the rural environment and the way of living and relating to the market. This is no longer just the space where its products are offered, but gains importance as a supplier of food and goods and services for families that become increasingly consumers of industrialized products. Funk, Borges and Salamoni (2006) complement stating that extra-agricultural activities allow a better quality of life for small producers and even though they are understood as exercising more than one paid activity, pluriactivity stands out, currently, through multiplicity in different ways, in different time and space situations, including the form of production and the work relationships based on the way of life and the productive system of a small family unit. In the Santo Antônio do Abonari Community, in Presidente Figueiredo - AM, these changes are taking place much more through access to markets, than through the insertion in the cosmetics production chain. Direct contact with markets or through family members accelerates the process of modernizing these communities and increasing consumption of goods and services that incorporate new technologies and that require knowledge and mastery of these technologies become common and modify local habits. Thus, the objective of this article is to analyze the process of insertion of the Santo Antonio do Abonari Community, in Presidente Figueiredo AM, based on commercial practices in the biocosmetics industry. The article is structured in five sessions, the first comprising this introduction, the second the theoretical pillar, the third the adopted methodology, fourth the discussion of the results and finally the final considerations.

\section{BIBLIOGRAPHIC REFERENCE}

The Organic Planet (2008) considers that organic cosmetic products are made with raw material from extracts of plant and natural and non-synthetic origin. This fact becomes an 
important differential, since according to "Planeta Orgânico", about $99 \%$ of traditional products use synthetic materials such as oil derivatives. This quality control, required by national and international organizations, shows itself as an alternative capable of winning over a public that is increasingly concerned with health and the environment. Cosmetic companies are incorporating the international trend of using vegetable and essential oils. Genamaz (2012) states that the main medium and large companies that specialize in selling natural-based cosmetics are: Yves Rocher (French), The Body Shop (English), Biotherm (French), Clarins (French), Ushua (French), Rose Brier (American), Mahogany (American). Other cosmetic companies such as L'Oreal, Esther Laudel, Clinique maintained their production of cosmetics with a synthesized active ingredient, opening specific lines of products with a natural base to meet the growing demand of the natural consumer. The demand for this type of product grew as the general public perceived its quality and this change caused a movement in the traditional industries of this segment that made them invest in research and development of their own products or in the acquisition of companies already established, as shown by APEX-Brasil (2008), when stating that in the cosmetics market based on natural products, two groups of companies are distinguished: the first is specialized in natural products, using only these natural inputs in its raw material prima and the second group of companies are traditional cosmetics companies that seek to increase their sales by diversifying production for natural cosmetics or adding flavors, dyes and natural vitamins. IBD - Instituto de Biodinâmica - (2008) confirms such data by stating that the organic cosmetics market is growing in the world. Major players, such as L'Oreal (France), L'Occitanne (France), Lush (United Kingdom) and Aveda (USA), to name a few, are taking concrete steps in this direction and launching new products. He also mentions that L'Oreal bought the English Body Shop and the French Sanaflore, in other words, small specialized companies are being acquired by the big world cosmetics companies.

Revilla (2002) observes that the universe of Amazonian plants for use in cosmetics is practically unlimited, and that new species are registered every day, increasing the possibilities of their use as sources of vitamins, vegetable oils, essences, healing and others. Abrantes (2002) notes that the volume of production and sale of products based on natural products from the Amazon is still modest in relation to its potential and highlights that the sustainability of this activity is linked much more to the capacity to undertake than to the abundance of resources natural resources and regional vocation. Whereas extractivism is based on the production of goods whose useful natural resources are taken directly from the place of occurrence in nature (DRUMMOND, 1996). The industries needed to adapt and started to have their production cycles linked to the natural cycles, since the natural raw materials from the extraction have a certain time and a specific climatic zone to be harvested and, later, benefited, so the industries cannot interfere or manipulate this natural process. For this process of change, the corporate culture must be open to include new production processes and internal values. For Miller (1998), one must be committed to disturbing the natural internal balance of organizations and leading companies to consider new strategic possibilities created by the discoveries of their scientists to develop new processes, uses, products or devices. Becker (2002) considers that regional communities to develop are, now, increasingly obliged to use their strengths, through their adaptive capacities to the global insertion and the creation of jobs / occupations and regional incomes. However, the way of life of these populations, their relationship with the place where they live and the time that govern their lives are closely linked to the relationship with the forest, nature, legends, culture and local religiosity. When inserted in a production chain, this process changes and what was gradual and natural, becomes dynamic and often invasive. The companies that operate in the sector claim to adopt sustainable forms of production, however, they cannot see the importance of the social factor for the continuity of the process. Despite inserting the sustainability seal that guarantees the sale of their products, they are not concerned with improving the quality of life of the populations that supply their raw materials. They show ignorance or lack of interest in sustainable practices in relation to the environment and communities. In this sense, as Enriquez (2008) points out, in the Amazon the lack of knowledge and experience of those involved in the execution of sustainable development projects are the weaknesses that need to be addressed.

This problem is not unique to this community or the Amazon. Afonso (2012), when researching the pequi production chain in Minas Gerais, found, basically, the same problems in the relationship with the market identified in the production of buriti in the Santo Antônio do Abonari Community. a) low management capacity of community enterprises; b) lack of production scale to serve local and institutional markets; c) lack of productive infrastructure for processing, transportation and storage; d) ignorance about good production practices; e) difficulty in complying with health legislation; f) lack of credit and tax incentives for production. Thus, it is observed that despite having production and an interest in producing, the market is a great challenge to be conquered, its demands, the need for quick responses, commercial vulnerability due to the lack of defense and collection mechanisms, the demands regarding in terms of time and quality, these are realities that members, mostly farmers with low education, have difficulty in dealing with and end up becoming obstacles to the success of the activity. Batalha, Buainain and Souza Filho (2005) report that the main problem for family farmers is not to be found in productive techniques, but, above all, in understanding the functioning of markets, which requires articulation with the intra and extra association segments including new forms of negotiation and management practices of the production process and negotiations with other agents in the production chain. In a complementary thought, Enriquez (2008) completed a study on sustainability in communities in Amazonas and found that the main difficulties are the lack of monitoring along the production chain, mainly in commercialization, legislation and technological training that would be essential to aggregate value to biodiversity products. Considering this scenario, Social Responsibility should be practiced by companies, in order to balance this equation, promoting rural producers, training and qualification to become competitors Siqueira (2003), the concept is related to the repair of existing inequalities. This procedure must take place both at the human level and at the interpersonal level (training), performing a function that until then would have been the State's. When reviewing the specialized literature, it is noted that social responsibility is still a concept under construction, having so much connotation of clientelistic actions of an emancipatory nature, related to the sustainable development model (Vergara \& Branco, 2001; Zouain \& sauerbronn, 2002; Machado \& Lage, 2002). 
The systemic nature of sustainability is something that, when perceived by societies, increases the synergy between government, institutional and social actions. Understanding the interdependence and fragility of individual organisms within the variations of their ecosystem is essential for changing behavior and breaking social paradigms. In this regard Capra (2006) adds that understanding ecological interdependence means understanding relationships, changing the perceptions of the parts for the whole, from objects to relationships, from content to standard, understanding that a sustainable community is aware of the multiple relationships among its members, involving multiple interdependent feedback loops.

The sustainability of a given production process, of a community or region, will depend on unique factors, interrelated and with distinct economic, social and environmental values for each culture or society related to the resource in question. The interest in maintaining or exploring an environmental resource may boost or discourage a certain economic activity, therefore, one must understand not only the market or the production process, but also the environmental social relations that involve the activity to be implemented. For Enriquez (2008) in the state of Amazonas, the category "Products of Biodiversity" was appropriated due to the great interest expressed by the increased demand for biodiversity products, which resulted in public policies to promote support activities.

\section{RESEARCH METHODOLOGY}

Scientific research sought to investigate the oil production activity in the Santo Antônio de Abonari Community, seeking to know how it occurs, what influences it receives and how it interacts with the environment in which it operates. In general, the object of study should be explored through a look directed by a given science. However, from the diffusion of the environmental study, it was noticed the complexity of the interrelations that involve the issues studied with this focus, in this sense Capra (2006) emphasizes that the more we study the problems of our time, the more we realize which are systemic problems and cannot be understood in isolation. Thinking in a complex way unites knowledge and tools from different fields of science. The complex thinking method is the activation of anti-Cartesian and post-Cartesian principles, in the sense that it does not reject the results of reductionist science, but discovers the possibility of refusing its limitations, that is, it is not tied to the modeling of the proposed problems (Pena-Veiga and Nascimento, 1999). This research was characterized as a Case Study having as object of study the insertion of the production of buriti oil in the Santo Antônio do Abonari Community, where it was sought to analyze it in a systemic and complex way, with a holistic look within the reality in which is inserted. Yin (2010) places the case study as an empirical investigation that applies to the study of a contemporary phenomenon in depth and in its real life context, which is consistent with this case.

In addition to the bibliographic research, field research was carried out to collect data related to the case study. Therefore, in each phase, a specific methodology was developed that used a combination of tools from the social, economic and environmental sciences in the search for understanding the way of life, internal relations, social and economic organizations, forms of production and management of the natural resources that occur in the Santo Antônio do Abonari Community, at the same time that the historical process of insertion of the studied activity was recovered, the objective was to understand how the introduction of the buriti oil production activity occurred and influenced these aspects. In field research, observation techniques (participatory or nonparticipant) and the interview were essential instruments in all phases of seeking complementary information for a greater understanding of the studied reality. Direct interaction with family farmers provided a better understanding of the reality studied and analysis of the data collected. The explanatory research when trying to determine the reason, the causes of the studied phenomena, supporting scientific knowledge by analyzing the available material and pointing out the implications brought by the activities of collection, processing and commercialization of buriti oil for the Santo Antônio do Abonari community, at the same time that it continued to be descriptive in relating the forms of collection and production practiced in the Community. The nature of the research was qualitative, since the analysis of the data collected in the field research was done in order to consider the researcher's observations, the responses of the interviewees and the context in which they occurred as a way of confronting or supporting the data, seeking include subjective dimensions in the interviewees' speeches and responses. In a complementary way, quantitative analyzes were performed, using descriptive statistics.

\section{STUDY AREA: Santo Antonio do Abonari Community}

The Santo Antônio do Abonari Community was formed during the construction of BR 174 from remaining employees of the company SERRAGRO, a logging company authorized to operate in that location together with the Brazilian Army during the process of carrying out the work. With the end of logging at the site, some employees settled and took family members, constituting the first agricultural productive units in the community and had its second population boost with the construction of the Balbina Hydroelectric Plant in the 1980s. It is located in the municipality of Presidente Figueiredo Amazonas, at coordinates $01^{\circ} 19^{\prime} 39.9$ "S and 60²2'55.0" O, it is characterized as a rural location that is mainly concentrated in the Serragro Branch with exclusive access via BR 174, at kilometer 1,083 of this highway, $95 \mathrm{~km}$ from the municipal headquarters and $200 \mathrm{~km}$ from the state capital, Manaus (Figure 1). The community structure is formed by this main branch and by 4 vicinals, named numerically according to their position along the branch. The community's altitude varies between 78 and 108 meters above sea level. (SEMMA-PF, 2013). The climate is hot and humid and according to the Kbppen classification, type Am with an average rainfall of $1,750 \mathrm{~mm}$ in the rainy season and less than $60 \mathrm{~mm}$ in the dry season. The temperature varies between $23.5^{\circ} \mathrm{C}$ to $33.1^{\circ} \mathrm{C}$ with an average temperature of the coldest month always above $18^{\circ} \mathrm{C}$ and an average relative humidity of $85 \%$. It is surrounded to the north by the Wamiri-Atroari Indigenous Reserve and to the east by the APA Urubuí (SEMMA-PF, 2013). Because it is located in an area bordering the WamiriAtroari indigenous land, its area of expansion to the north has activities such as hunting and fishing reduced to the current limits of the community itself. When studying the farmer in the Brazilian Amazon, including the Santo Antônio do Abonari Community, it is necessary to understand that the entire population that lives far from urban centers is both a farmer and an extraction worker. Extractivism is in the culture, in the way of life of the Amazonian people, so one activity does not exclude the other, but complements it. 


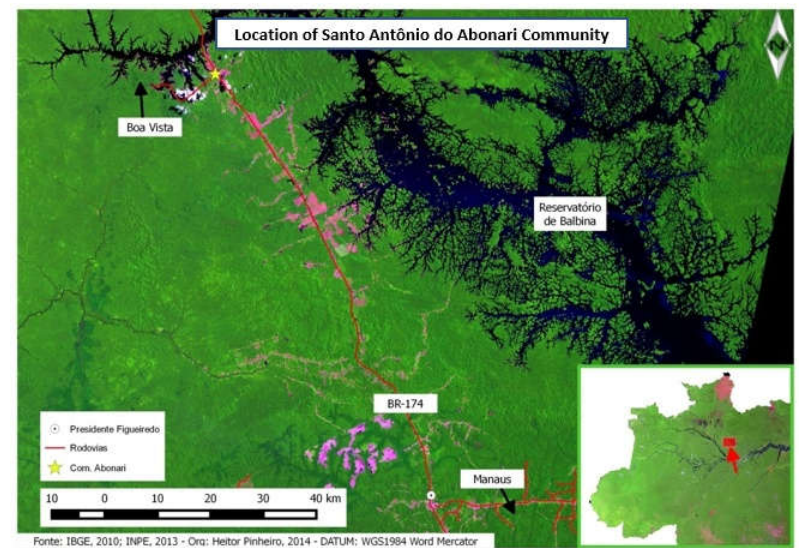

Fig. 1: Geographic location of the Santo Antônio do Abonari Community, Presidente Figueiredo, AM - Brazil

Source: IBGE, 2010; INPE, 2013. Org. Heitor Pinheiro, 2014.

The survival of this farmer, in many moments, depends on hunting, fishing and the collection of fruits, seeds, vines, wood and other raw materials found by him in the region and the cultivation of foodstuffs, with emphasis on cassava, supply of flour and starch, the basis of their diet and the farm around the residence, whose production supplies the family with food and natural medicines. Noda et al (2001) state that the sites or yard are based on natural biodiversity, involve the management of trees, shrubs and herbs of multiple uses, as well as the creation of small animals, it is a privileged space for family socialization. The Santo Antônio do Abonari Community is part of this Amazon mosaic. Family farming has been practiced by its residents since its formation as a source of food and income and finds extraction as a complement that contributes to the family diet and the acquisition of goods for the family. For this reason, it is essential to understand the process of historical formation, social organization and how public and private social facilities meet the needs of the residents of this community.

In this community, the components of the production system are similar to those of traditional farmers in Alto Solimões, described by Noda, Noda and Silva (2013) and also consist of: Cultivation; Small farm, yard or yard; Capoeira or fallow area; Extractivism and, Creation of small animals, according to the following specifications. In more distant places are the plantations called swiddens, with an emphasis on manioc, manioc, banana and açai. The latter gained momentum through a donation of seedlings made by IDAM.

\section{RESULTS AND DISCUSSIONS}

Buriti Production: Buriti production in the Santo Antônio do Abonari Community has always been expressive and stood out in the municipality of Presidente Figueiredo. However, this fruit traditionally had as its main destination the ice cream factories and fairs in the capital Manaus. Since 1992 the community has been working with the sale of buriti, when it sold an average of 1,000 (thousand) bags of 50 kilos of fresh buriti per harvest. In 2002, company C, located in the Industrial Pole of Manaus, was looking for a location where buriti production was abundant to supply its demand for buriti oil and serve customers that produce cosmetics. During a visit to the Secretary of Community Action of Presidente Figueiredo, he was nominated by the Santo Antônio do Abonari community as the largest supplier of the fruit in the municipality. And so, the community was identified as a potential producer. The first contact was made by Mr. J.D., CEO of company C. with Mr. J.B.F., president of the community. On their first visit to the community, the two did an reconnaissance of the area, where the buriti trees were observed and from then on the Company C - Abonari partnership began. Company $\mathrm{C}$ held meetings in the community with the aim of publicizing the project and mobilizing community members for local participation. At the beginning of the operationalization of the activities, the company sought a partnership for the supply of dry pulp, a very simple artisanal process that was quickly assimilated by the community. In the years 2002 and 2003, the process consisted of harvesting the fruits, removing the pulp and drying in the sun on tarps. In the third year in 2004, the production process increased, requiring that the dried pulp be sieved before delivery to remove the peel and other residues.

During this period, the activity was developing well, the community members were engaged, the entire harvest was sold to the association and all production was purchased immediately by company $\mathrm{C}$. There were 10 people working at the plant and 9 families selling buritis in bags to the Association. . Buriti income became an important component of the family budget in the community, equaling or exceeding the income generated by the sale of manioc flour, one of the main sources of domestic income for these farmers. However, in 2005, company $C$ sought new partnerships for the development of a project that would offer the community a structure that would allow the production of buriti oil by the members themselves, adding value to production and bringing more income and development to the community.

Buriti Oil Extraction Structure: At this stage of the project, it was necessary to set up a structure that would allow the extraction of buriti oil and the training of community members to operate the machines. The $\mathrm{CDH}$ with resources from the FDH - Human Development Fund of the State of Amazonas financed R \$ 82,000.00 (eighty-two thousand reais) on a nonrefundable basis, 55 thousand reais were used to purchase machinery in São Paulo. In addition, the Ministry of the Environment allocated R \$ 40,000.00 (forty thousand reais) for the construction of the warehouse, which currently functions as the kitchen of the association. In 2005, there was also the Smart Wood Certification. To this end, a survey and production monitoring was carried out by AFLORAM technicians and by the IMAFLORA team. This report includes a visit to 15 properties and in 2006 the certification of only 8 properties, with the implementation of Management Plans. The NGO Amigos da Terra also participated in the process. It is observed that there was a great effort to support and create the necessary structure for the development of the activity, the concern with production and environmental preservation, as well as the market acceptance of the product through the Environmental Certification and the sustainability appeal. However, the third pillar of sustainability was also overlooked in this project, human resources were lacking, the social side was missing. Low schooling, isolation and lack of technical training for residents were not considered or placed as an essential factor for the success of this activity, although some courses were offered, basic information such as specification regarding product quality, acidity, productivity were revealed during the implementation of the project.

Production Management: Since the beginning of the activity's implementation, problems related to management and production have been observed and, as the processes became 
more complex, the obstacles for the production to be well accepted by the companies and the community reached financial gains, social return and confidence in the activity, in order to maintain the motivation and interest of the social actors involved in the production. The problems started in 2006, when the pulp production was replaced by that of buriti oil. In this phase, although initially, there was a great commitment by Organs municipal and state bodies and the Association has been environmentally certified by SMARTWOOD, the machines have also been installed and even company $\mathrm{C}$ has followed the whole process, many aspects were ignored. This was the general context that led to the interruption of activity in 2007, consequently, resulting in the loss of all the effort undertaken. According to the report of the process managers and leaders of the period, the company did not sign a formal contract with the community members, nor did it offer training on good practices in the production and storage of oil. After the installation of the machines, it requested the production of 350 kilos of oils for which $\mathrm{R} \$$ 45.00 reais would be paid per kilo, without specifying the need to meet certain quality standards, especially to maintain the acidity of the oil produced below. $10 \%$.

At this time, the community formed by family farmers was carrying out its first industrial production. They had never supplied or related to specialized industries. Most of its associates had not completed elementary school, did not have the knowledge of industrial dynamics and were not prepared for contact with the competitive market that requires quality standards and technical specifications regarding the product to be delivered. It was found, therefore, that all these requirements were far from their reality. After the production of 350 kilos of oil requested by company $\mathrm{C}$, the CEO of this company came to the community accompanied by a professional in the chemical area, which surprised the community. After the analyzes, it found an acidity of $22 \%$ in the product. A fact that led the company to abandon the purchase, since the maximum acidity accepted by the company would be $10 \%$. Thus, company $\mathrm{C}$ made the whole process unfeasible, lacking with commitment and social responsibility. The community was abandoned with all the production and its commitments to the community members who were involved in the production process. This attitude caused astonishment and indignation in the community that did not accept this position. Thus, began the process of breaking the bond in the partnership between Company C - Abonari and the demotivation of community members in participating in the project.

In this process of insertion of the Santo Antônio do Abonari community, there is an unpreparedness and ignorance of the managers of company $\mathrm{C}$ regarding this type of project, considering that a company transforms family farmers into its suppliers. It is necessary to recognize the fact that these farming communities need legislation for their protection and the biodiversity involved in production processes. In addition, they need participatory technical advice to avoid problems in terms of time and quality. They must also be supported by fair contracts in accordance with current legislation. To include these societies in their production chains, companies need to be aware of social responsibility and the ethics necessary to manage these relationships. After the breach of the verbal agreement, the Association had to resort to public agencies to recover part of the applied work and to ensure that the company received the payment of the promised amount. The rest to be received was donated by the City Hall, for payment of at least the expenses incurred during production. Thus, the Association was unable to continue developing the activity, as the only buyer of its production had broken with the partnership. After the breakdown of the partnership between company $\mathrm{C}$ and the Association, with the lack of perspectives on the future of production and the inexperience with market mechanisms, many of those who participated in the initial process of extracting buriti for oil production left this activity and the entire production process was dismantled.

Development of New Partnerships: Only in 2011, when Mr. J.G. became president of the community and sought partnerships, did the process of reactivating the production of buriti oil begin again. At this stage, they needed to seek out new consumers and the process changed. They had the support and encouragement of a professor and researcher from the Federal University of Amazonas who had participated in the implantation of the mini-plant, and a candidate for mayor of Presidente Figueiredo, both became fundamental for the connection between the community and the buyer market, including providing a financial contribution for the initial working capital, in the amount of $\mathrm{R} \$ 20,000.00$. With this new impulse, the Association reorganized and resumed production, the sum of which was 663 kilograms of oil with an acidity of $4.41 \%$. This demonstrates that the Association with working capital, training of associated farmers and monitoring are able to produce the oil with the necessary quality. As the payment was guaranteed and immediate, the farmers themselves delivered the fruits harvested at the headquarters of the association, as this way the price was higher than that collected on the properties by the association's team.

The entire production was sold, the loan of $\mathrm{R} \$ 5,000.00$ to the teacher was paid and the net balance was positive in approximately $\mathrm{R} \$ 12,000.00$ (twelve thousand reais). However, they were unable to pay the R \$15,000.00 loan to the candidate for mayor. As an aggravating factor, two financial statements were presented in that year: in one the costs totaled $\mathrm{R}$ \$ 20,216.30 and in the other totaled $\mathrm{R}$ \$ 26,462.30. In other words, in none of the cases would the values obtained from the sale be sufficient to cover production costs. Mainly, taking into account the need to settle the loan for the mayoral candidate. Even though it was considered a success that the Association closed the working capital period of approximately $\mathrm{R} \$ 12,000.00$, the members did not accept the rendering of accounts and the managers had difficulties in explaining the differences in the results presented. Confidence in the process and management credibility are beginning to be weakened within the community. The apparent success stimulated the community and in 2012, 600 kilograms of oil were produced. To achieve this result in a non-harvest period, the Association purchased buriti fruits from a seller in the state of Roraima, whose production occurs in another period. Buriti fruits purchased exceeded the 24-hour period between collection and delivery to the Association's mini-mill and the oil produced showed acidity above the maximum established by the companies $(10 \%)$. Thus, the oil produced cannot be sold at market price and was sold to a company based in the state of Pará, which was sent through the port of Manaus and the total amount earned by the Association was R \$ 8,700.00 (eight thousand and seven hundred reais). The gains were much lower than in the previous year and there was no record of accountability, informing the Association's real financial situation. 
In the transaction, communication problems occurred, which resulted in the return and reshipment of the first batch, a fact that led to extra costs for the Association. Besides this, the associates affirm that the company acted in bad faith, because when it received the second shipment, it refused to make the payment. After a period of negotiations, the company proposed a payment in installments of $\mathrm{R} \$ 500.00$, which took the entire year of 2014 to pay the total debt. With this, it is possible to verify once again the weaknesses of the Association in the face of a competitive market, with companies in distant cities and without efficient tools of control and collection, resulted in financial commitment and, consequently, in lack of available resources to proceed with The activities. Once again, the purchasing companies behaved within the logic of the market, which seeks to optimize financial results, and outside ethical standards, as they broke verbal commercial agreements and took advantage of the isolation and difficulty of access to collection instruments for supplying farmers to postpone payments and to unduly benefit from the situation.

Perception of Future Business: In general, in the discourse and attitudes of farmers, it is clear that these denote a lack of confidence in the future of the buriti extraction activity for the generation of monetary income. Among the factors to be considered, management capacity is another worrying factor. Simple decisions and accountability are dominated by some associates, but when there is some complexity, such as negotiating deadlines and mainly resolving internal conflicts, deficiencies are perceived that can lead to problems in the production and commercialization of buriti oil. As for the social factor, it is expected that there will be a return to the community, an improvement in income, in community services, in people's quality of life. It can be said that when the process of extracting buriti for oil production was started, the associates showed interest in participating in the meetings, in the collection and production and wanted training courses to improve working conditions. However, the training was slow to arrive and was very restricted, courses for climbers and good practices only came after the break with the company $\mathrm{C}$., that is, when the project lost its link with the rest of the chain productive and sought to find its own channels for distribution. Enriquez (2008) states that, when confronting the researchers' perception with the reality of the communities, it is realized that extractive activity is insufficient to guarantee family livelihood, agroextractivists need to resort to other sources, mainly due to the lack of strategies to add value and diversify production. The production of buriti oil in the Santo Antônio do Abonari community, in a superficial view, can be considered as a regional vocation, as an endogenous development factor. However, when analyzing more deeply, it is observed that, traditionally, the community has already been related to the ice cream industries in the city of Manaus, which can easily access and maintain a relationship to the present day. Contrary to what happened with the cosmetics industry, since it is very far from the community. The introduction of a rural community in the production chain of a large and competitive industry, such as cosmetics, must be thought of holistically and systemically. Holistic, because it is necessary to think about the community when relating to the whole, that is, with the global competitive industry and how this industry will relate to the community. How they will form the same system, even living such different realities. In the case of the Santo Antônio do Abonari Community, the project was imposed without offering the necessary technical bases for its development, not even basic information such as the need for acidity below $10 \%$ was passed on. The company lacked commitment, as this technical problem could have been easily overcome as demonstrated by the production, by the community, of 663 kilograms of oil with acidity below $4 \%$ and in 2014 , when it achieved an acidity index of only $2 \%$. The company committed to the purchase of the oil produced broke the link established with the Community without worrying about the future of those involved, after having brought about profound changes in the routine, in the lives of people and in the social organization of production in the community under study. The Santo Antônio do Abonari Community was inserted in the cosmetics production chain, with the objective of promoting the improvement of the quality of life of this population and the maintenance of its natural resources. In this way, the process of insertion of this community in a global market and the development of this activity must be analyzed and understood as a way to contribute to the academic debate on the sustainability of these actions.

FINAL CONSIDERATIONS: The inclusion of Amazonian communities in the productive chain of industrialized products is usually defended as an option for sustainable development for these communities and for improving the production process as a whole by reducing chemical bases and the use of sources of ecological raw materials. However, experience shows that, in many cases, the activity is started and later abandoned by the prospecting companies. The Santo Antônio do Abonari Community became the object of this study due to its insertion in the cosmetics production chain as a supplier of buriti oil to industries that produce or benefit this product for companies in this sector. The insertion of the Santo Antônio do Abonari community arose from the search for a source of raw material for a cosmetics industry. Although the project initially received support from government agencies, NGOs, environmental certification and monitoring by the company interested in buriti oil, many factors were not considered. The lack of commitment and social responsibility of the purchasing companies, added to the limitations regarding the understanding and relationship of family farmers with the global competitive market in which they were inserted, became an impediment to the sustainability of this activity in the economic and social dimensions.

The idea of using regional potentials or vocations as competitive differentials for regional development, in the case of the Santo Antonio do Abonari Community, did not envision the difficulties in meeting the technical specificities of global industries in a location far from large centers, with little infrastructure and unskilled labor for production and relationship with the markets, this context led to the disruption and stagnation of activity. It appears, therefore, that companies need to seek ways to relate to these communities, offering not only machinery and equipment, but technical, administrative and financial training, following the process in the initial stages, in order to create a link with community, a relationship of trust that allows interaction and the exchange of experiences and knowledge so that when obstacles or difficulties arise they can be resolved in partnership, reducing the differences between the logic of the family farmer and the organizational culture of the business world. The main problem, however, was the breach of agreements that demonstrates the lack of commitment and social responsibility of companies towards family farmers. In general, despite using the sustainability discourse, companies demonstrate to aim only at profit when making purchase offers at prices below those practiced in the 
market and by failing to comply with the agreements established, since these are made verbally and sometimes by through third parties, which makes it difficult to collect deadlines and amounts. Another fundamental point is the lack of formal contracts that comply with current legislation and protect these populations.

Based on the case study of the Santo Antônio do Abonari Community, it was found that the insertion of a community of family farmers in the global economy needs to be planned through an in-depth study involving a multidisciplinary team for the initial assessment and monitoring during the first productive cycles so that local populations can assimilate knowledge and management, production and storage practices to ensure quality within the technical specifications of each product and conditions for maintaining the activity through good management and financial control practices. This monitoring must also be done by the public sector, mainly with the offer of technical assistance and with the supervision and search for commercial agreements so that they guarantee the remuneration of those involved in the production and in compliance with the current legislation and contracts and the payment agreement. in terms and combined values, in order to bring community confidence in the activity, financial return and real improvement to the lives of these populations. In this way, changing some practices, this activity can become sustainable, generating a virtuous circle of growth. It would then be possible to promote local development for communities supplying raw materials, while meeting the demand of socioenvironmentally responsible companies, which produce goods and services for conscious consumers, concerned with people and the environment.

\section{REFERENCES}

Abrantes, Joselito S., Bio(sócio)diversidade e empreen dedorismo ambiental na Amazônia. Rio de Janeiro: Garamond, 2002.

Afonso, Sandra R. A política pública de incentivo à estruturação da cadeia produtiva do pequi (Caryocar brasiliense). [Distrito Federal] 2012. 162 p.

APEX-Brasil, - Agência de Promoção de Exportação e Investimentos. 2008 Endereço: http://www.apexbrasil.com. br/interna.aspx?id=1. Acesso em: 19/08/2015.

Batalha, M. O.; Buainain, A. M.; Filho, H. M. de S. Tecnologia de Gestão e Agricultura Familiar. Gestão Integrada da Agricultura Familiar. São Carlos:EdUFSCar, 2005.

Becker, Dinizar F.(org). Desenvolvimento sustentável: necessidade e/ou possibilidade?4 ed. Santa Cruz do Sul: BATISTA, Djalma. O complexo da Amazônia - Análise do processo de desenvolvimento. $2^{\mathrm{a}}$ Ed. Manaus: Editora Valer, Edua e Inpa, 2007.

Capra, F. A teia da Vida: uma nova compreensão científica dos sistemas vivos. 10 ed. São Paulo: Cultrix. 2006.

Clemente, Ademir e HIGACHI, Hermes. Economia e desenvolvimento regional. São Paulo: Atlas, 2000.

Drucker, Peter F. As novas realidades no governo e na política, na economia e nas empresas, na sociedade e na visão do mundo. São Paulo: Pioneira, 1989.

Drummond, J. Augusto. 1996. A extração sustentável de produtos florestais na Amazônia brasileira: vantagens, obstáculos e perspectivas.Estudos Sociedade e Agricultura 6: 115-137.
Enriquez, G.E.V., Desafios da sustentabilidade na Amazônia: Biodiversidade, cadeias produtivas e comunidades extrativas integradas. Tese de doutorado. 460 p. Centro de Desenvolvimento Suntentável, Universidade de Brasília, Brasília, 2008.

Genamaz, 2000. Rede interinstitucional para conservação e uso dos Recursos Genéticos Amazônicos. Endereço: www.genamaz.org.br/estudcosmetico01.html. Acesso em: 15.03.2012.

Homma, A.K.; Matos, G.B.; Menezes, A.J.E. Manejo de bacurizeiros como alternativa econômica para áreas degradadas da Amazônia. Ribeirão Preto, 24 a 27 de Julho de 2005. Sociedade Brasileira de Economia e Sociologia Rural - XLIII CONGRESSO DA SOBER. In http://www.sober.org.br/palestra/2/176.pdf, em 10 de junho de 2009.

IBD. Instituto de Biodinâmica. 2008. Endereço: http://www.ibd.com.br/News_Detalhe.aspx?idnews=99.

Acesso em: 19/03/2011.

Miguel, Laís M. Uso sustentável da biodiversidade na Amazônia brasileira: experiências atuais e perspectivas das bioindústrias e cosméticos fitoterápicos. 2007. 160 fls. Dissertação (Mestrado em Geografia Humana). Programa de pós-graduação em Geografia Humana da Universidade de São Paulo.

Miller, J. DuPont. In: Kanter, R.S.; KAO, J.: Wiersema.F; (Ed) Inovação: pensamento inovador na $3 \mathrm{M}$, DuPont, G.E., Pfizer. e Rubbermaid. Tradução: June Camargo. São Paulo: Negócio Editora, 1998. p. 75-104.

Noda, Sandra N., et al.Utilização e apropriação das terras por agricultura familiar amazonense de várzeas. In: DIEGUES, A.C. MOREIRA, A.C. Espaços e recursos naturais de uso comum. São Paulo: Núcleo de Apoio à Pesquisa sobre Populações Humanas e Áreas Úmidas Brasileiras, USP, 2001.

Noda, S. N. Noda, H. e Silva, A.I.C. Socioeconomia das unidades de agricultura familiar no Alto Solimões: formas de produção e governança ambiental. In: NODA, H. et al. Dinâmicas socioambientais na agricultura familiar na Amazônia. Manaus, AM: Wega, 2013.

Pena-Veiga, A., Nascimento, E.P. (Org.) O pensar complexo: Edgar Morin e a crise da modernidade. Rio de Janeiro: Garamond, 1999.

Planeta Orgânico. Planeta Orgânico. In $<$ http://www.planetaorganico.com.br/site $>$. Acesso em: $15 / 11 / 2010$.

Revilla, Juan. Apontamentos para a cosmética Amazônica. Sebrae - AM/ INPA, 2002.

Semma-PF. Secretátia Municipal de Meio Ambiente de Presidente Figueiredo. Plano de Desenvolvimento Sustentável e Conservação do Município de Presidente Figueiredo, 2013.

Siqueira, E. S.; SPERS, V.R.: Responsabilidade Social: o potencial transformador da atuação social das empresas. Itu: Ottoni Editora, 2003.

Suframa. Endereço: http://www.suframa.gov.br/ modelozfm opcaoinvest am pr bioindustria.cfm. Acesso em 19/03/2012.

Vergara, S. C., Branco, Paulo Durval. Empresa Humanizada: a organização necessária e possível. Revista de Administração de Empresas - RAE. São Paulo: FGV/EAESP, v. 41, n. 2, p. 20-30, abr./jun.,2001.

Yin, R. K. Estudo de caso: planejamento e métodos. 4. ed. Porto Alegre: Bookman, 2010. 